\title{
Capital Export and Economic Growth - The Case of China
}

\author{
Ping Han* \\ School of Economics and Management, Shandong Jiaotong University, Jinan, Shandong, China. \\ *Corresponding Author: Ping Han, School of Economics and Management, Shandong Jiaotong \\ University, Jinan, Shandong, China.
}

\begin{abstract}
The promotion of the "Belt and Road" policy and the gradual opening of capital account have led to an increase in China's capital export. At present, China's capital export mainly exists in the form of foreign direct investment and securities investment. How will capital export affect China's economic growth? The answer to this question is conducive to our accurate judgment of China's current capital export. Also, it is helpful for reasonable and effective supervision, so as to promote healthy and sustainable development of economy. The article discuses that China's capital export is mainly dominated by state sovereign funds, enterprises and individuals. It also concludes that capital export in china had slightly promotion to economy growth. But, as main form of capital export, direct investment and securities investment had not promoted economic growth.
\end{abstract}

Key words: capital export; economic development; direct investment; sovereign wealth.

\section{INTRODUCTION}

\subsection{Capital Export}

The concept of capital export emerged in the mid-19th century, accompanied by large-scale investment and plunder of colonies by developed countries. Marx first proposed the concept of capital export, he pointed that capital export is capitalist countries investing or lending to other countries in order to obtain high profits by the use of excess capital. Marx's Capital Theory reveals the nature of capital export in developed countries and its impact on the world economy. Marx believes that capital export is the result of capital's pursuit of surplus value and capitalist socialized product. The essence of capital's pursuit of surplus value makes it necessary for capital to expand across national borders, thus result capital export. The capital export of capitalist society exists in the form of commodity capital export and lending capital export. "Excess capital" is the necessary material basis for capital export. Due to the existence of excess capital, domestic rate of return is reduced, in order to pursue higher revenue; capital needs to be exported abroad. In addition to examining capital export in the production field, Marx also analyzed the impact of capital export on the economy from the perspective of production relations. He pointed that on the one hand, capital export has changed the previous self-sufficiency production relationship, making countries and nations interdependent and interconnected. On the other hand, it has also achieved control to colonies and semi-colonies, terminating these countries' Self-develop process. Finally, Marx also discussed the relationship between the economic crisis and capital export. capital export temporarily eased the inherent contradiction of capitalism, it also pushed the contradiction to a broader scope, and increased the possibility of crisis to erupt internationally. Based on Marx's theory, Lenin deepened the theory of capital export. He divided the capital export into two forms, one is productive capital export, and the other is lending capital export. Lenin believes that the excess capital of developed countries mainly flows to economically backward countries. Capital export must satisfy two conditions, one is excess capital in a few developed capitalist countries, the other is backward countries have the possibility of developing capitalism. Finally, Lenin pointed that the inevitable result of capital-flow from developed countries to developing countries is economic stagnation in capital-exporting countries and the capitalization of capital-importing countries.

Later studies found that capital export is not only conducted by developed countries. Due to the inequality of resource endowments in countries around the world, most countries in the world both 
have capital export and capital import. There are "vertical flows" of capital from developed countries to developing countries, "horizontal flows" among developed countries and developing countries, and "reverse flows" from developing countries to developed countries (Xiao Weiguo, Cai Zhiqiang, 1999).

So far, we can define capital export as an investment or loan made by government or private institutions to obtain high profits or interest, the capital exporting country may be a developed or developing country. There are two forms of capital export: productive capital export and lending capital export. productive capital export refers to the establishment of foreign companies to engage in production and operation activities in the form of direct investment; while lending capital export refers to indirect investments such as loans provided by foreign governments or private individuals, purchase of foreign bonds and stocks (securities investmeng).

\subsection{Effect of Capital Export on Economic Growth}

The influence of capital export on a country's economic growth can be affected through foreign trade (Buckley\&Casson, 1981; Markusen, 1995), employment ( (Hawkins, 1972; Hamill, 1992) , reverse technology spillover (Kogut \& Change, 1991), and capital appreciation (Macdougall, 1960). From the perspective of the foreign trade and the employment, capital export may both promote economic growth and inhibit it. While, from the perspective of reverse technology spillover and capital appreciation, capital export can promote a country's economic growth. Therefore, the effect of capital export on a country's economic growth is dubious. Nevertheless, Studies by Gilpin (1975), Dunning (1991), etc. have all proved that direct investment as the main form of productive capital export has a significant promotion effect on the economy exporters. China's domestic researchers also shows that foreign direct investment from developed countries such as the United States, Britain, and Japan has a significant role in promoting economic growth (Li Xing, Li Xiaojuan, 2006).

\section{METHOD OF CHINA'S CAPITAL EXPORT}

The definition of capital export now is different from that of Marx and Lenin's analysis. Marx and Lenin's definition is based on the essence of capitalist exploitation. It is considered that capital export is the means by which imperialism exploits and oppresses backward countries. With the development of international economy, the links among countries have become closer, the internationalization of production and consumption as while as the globalization of capital have become normal. Therefore, capital export is no longer a patent of developed countries or capitalist countries. Capital exports conducted by developing countries are possible. It has become a way to be equal and mutually beneficial, to share common prosperity, and to learn from each other. On the whole, there are two main types of foreign capital export in China: state-led sovereign wealth funds and market-led investment by enterprises and individuals.

\subsection{Sovereign Wealth Fund}

Sovereign wealth fund is a special kind of wealth management which is different from private wealth fund; it is also known as sovereign investment fund. The International Monetary Fund (IMF) defines it as a special investment fund created and owned by the government that holds foreign assets for long-term purposes. Sovereign wealth fund invest worldwide, including real estate, financial assets (stocks and bonds), precious metals and hedge funds. The funds come from trade surpluses, export earnings from commodities such as oil and minerals, and foreign exchange reserves owned by the central bank. Since the 1950s, global sovereign wealth funds have developed rapidly. As of December 2017, nearly 50 countries and regions have set up sovereign wealth funds. The global sovereign wealth fund assets have exceeded 7.4 trillion US dollars. Most of the sovereign wealth funds are located in Asia and the Middle East. For example, in the Middle East oil-producing countries, Southeast Asian countries and China, the foreign exchange reserves far exceed the scale required to maintain external payments and currency stability. If foreign exchange reserves are always invested in traditional high-current assets, and their low returns cause huge waste of resources, it is a new choice to build sovereign wealth funds and optimize investment portfolios through expert management to obtain high returns.

There are four main forms of global sovereign wealth funds: the first kind is a stable sovereign wealth fund, which is established to smooth national income and reduce the impact of unexpected fluctuations in national income on the economy and budget. Most of the countries that have established such funds are countries that rely heavily on natural resources for export to earn foreign 
exchange. Due to the high volatility of their natural resources, the establishment of funds can accumulate surplus in the years when natural resources output and large export revenues are large. Used for long-term investments and the return on investment is used to smooth the decline in income from years of low resource output. Norwegian government's global pension fund falls into this category. The fund is managed by the Norwegian Central Bank Investment Management Corporation (NBIM). Fund capital comes from export revenue generated by the oil and gas sector. The second kind is the sterilized sovereign wealth Funds, which are mainly used to assist the central bank in diverting excess foreign exchange reserves. As the surge in foreign exchange reserves will bring greater pressure on the appreciation of a country's currency, in order to alleviate this pressure, some countries have separated the surge in foreign exchange reserves to set up a special sovereign wealth fund to invest and manage foreign exchange reserves. At the same time, it stabilizes its exchange rate. China Investment Co., Ltd. is a typical sterilized sovereign wealth fund. The third kind is the savings sovereign wealth fund, which was established to smooth the national wealth and accumulate wealth for future generations. Such funds are represented by the Middle East countries and are designed to cope with the decline in pension income caused by aging and natural resource income decline. The fourth kind is strategic sovereign wealth funds, which are established to be global. Resources are allocated within the scope to support national development strategies and support the development of domestic enterprises. Singapore's Temasek Holdings is a typical one. According to data released by the US Sovereign Wealth Fund Research Institute (SWFI), until April 2020, the rankings of the world's top 10 sovereign wealth funds (see Table 2-1), the sovereign wealth fund funds of the Middle East and other oil producing countries are mainly From oil and gas exports, other countries' funds are mostly comes from non-commodities such as foreign exchange and pension funds. At present, there are four sovereign wealth funds in China, namely the SAFE Investment Company (established in 1997), National Council for Social Security (established in 2000), China Investment Corporation (established in 2007), and China-Africa Development Fund (established in 2007). As of April 2020, the top three funds ranked the top 10 in the world.

Table2-1. World Main Sovereign Wealth Funds

\begin{tabular}{|l|l|l|l|l|}
\hline Rank & Country & Name & $\begin{array}{c}\text { Total } \\
\text { (billion dollars })\end{array}$ & $\begin{array}{l}\text { Founding } \\
\text { time }\end{array}$ \\
\hline 1 & Norway & Norway Government Pension Fund Global & 11866.7 & 1990 \\
\hline 2 & China & China Investment Corporation & 9406.04 & 2007 \\
\hline 3 & Abu Dhabi & Abu Dhabi Investment Authority & 5796.21 & 1976 \\
\hline 4 & Hong Kong & $\begin{array}{l}\text { Hong Kong Monetary Authority Investment } \\
\text { Portfolio }\end{array}$ & 5398.65 & 1993 \\
\hline 5 & Kuwait & Kuwait Investment Authority & 5336.50 & 1953 \\
\hline 6 & Singapore & GIC Private Limited & 4400 & 1981 \\
\hline 7 & China & SAFE Investment Company & 4178.45 & 1997 \\
\hline 8 & Singapore & Temasek Holdings & 3753.83 & 1974 \\
\hline 9 & China & National Council for Social Security Fund & 3249.96 & 2000 \\
\hline 10 & $\begin{array}{l}\text { Saudi } \\
\text { Arabia }\end{array}$ & Public Investment Fund & 3200 & 2008 \\
\hline
\end{tabular}

\subsection{Productive Capital Exports}

So far, there is relative little information about China's sovereign wealth funds investment. The known companies engaged in productive capital export are China Investment Corporation, China-Africa Development Fund and National Council for Social Security Fund. China Investment Corporation has three subsidiaries, namely Central Huijin Investment Corporation ("Central Huijin" for short), China Investment International Corporation ("CIC" for short), and China Investment Offshore Direct Investment corporation ("CIC Offshore" for short). Central Huijin mainly participates in domestic commercial banks, securities companies, insurance companies and other institutions. CIC International and CIC Offshore are responsible for foreign investment projects. CIC Offshore mainly conducts with overseas direct investment projects of CIC and multi-bilateral fund management. Since its establishment, CIC Offshore has been actively engaged in overseas high-quality project investment. The investment projects involve Germany, Australia, Turkey, the United Kingdom, Brazil and other countries. However, due to the limitations of information transparency, the specific investment amount is Unable to know. The China-Africa Development Fund is affiliated to the National Development Bank to support China-Africa economic and trade cooperation as its main 
business. The China-Africa Development Fund does not invest directly in Africa, but mainly invests and participates in Chinese companies and projects that invest in Africa and conduct economic and trade activities. Since its establishment, the fund has actively supported China-Africa economic and trade cooperation, focusing on a number of projects in agriculture, processing and manufacturing, infrastructure, industrial parks and resource development, which has promoted the investment of Chinese enterprises in the African region and infrastructure construction for African countries.

Productive capital export driven by market began in the late 1970s, with the advancement of reform and opening up, the government put forward the slogan of "going abroad to run enterprises". Some large state-owned enterprises represented by China Metallurgical Construction Group, Bank of China and China International Trust and Investment Corporation have set up overseas branches and representative offices to meet the needs of overseas trade activities. Due to the shortage of domestic foreign exchange during this period, foreign investment projects need to be approved by the State Council, so the amount of investment is relatively small. In 1985, the Ministry of Foreign Trade and Economic Cooperation issued the "Approval Procedures and Management Measures for Opening Non-trade Joint Ventures in Foreign Countries", expanding the scope of overseas investment from trade enterprises to non-trade enterprises, including large and medium-sized industrial enterprises and comprehensive Financial enterprises have further promoted the development of overseas investment. After 1992, with the continuous advancement of the socialist market economic systems, private enterprises represented by Huawei and ZTE have also started overseas investment activities. Since 2000, with the rapid development of China's economy, the continuous surplus of foreign trade has led to an increasing stock of capital. The transition from a capital-poor country to a capital-rich country has made China have the basic conditions for foreign investment, more and more domestic Companies are investing in the global market. in 2015, foreign exchange management of overseas direct investment has basically realized convertibility, providing full support for domestic institutions participating in international economic cooperation and competing in foreign markets. As of the end of 2019, China's foreign direct investment covers more than 190 countries and regions around the world. Totally 24,400 domestic investors set up oversea enterprises, foreign direct investment amount totaled to 120 billion US dollars.

\subsection{Lending Capital Export}

As national sovereign wealth funds, SAFE, the SAFE Investment Company, National Council for Social Security and China Investment Corporation all engage in lending capital. The lending is mainly in the form of bonds, stocks and funds. At present, the foreign exchange assets of SAFE are mainly invested in bond and stock markets in developed countries. According to report from US-China economy under the US Congress, a large part of traditional investment of SAFE is US Treasury and other dollar-denominated fixed-income bonds. National Council for Social Security began invests abroad from 2006. Its overseas investment assets cover global stocks, bonds, foreign exchange and others. CIC offshore is also an institution specializing in overseas capital lending. Its business covers overseas market stocks and bond investments, hedge funds, real estate investment, entrusted investment.

Besides lending from state sovereign funds, government aid loans, export credits, and QDII are also forms of lending capital export. Government aid loans are generally provided by developed countries to developing countries, which are long in borrowing period and with low interest or no. Usually government aid loans are earmarked and be required to import merchandise from lender countries, or for the development of certain aid projects. Export credit is generally used to encourage domestic exports, enhance international competitiveness, and provide low-interest loans to domestic exporters or foreign importers to alleviate the difficulties of domestic exporters or meet the needs of foreign importers. The credit provided to domestic exporters is called seller credit; the one to foreign importers or importer banks is called buyer credit, which is a kind of lending capital export.

In addition to government aid loans and export credits, domestic individuals and enterprises invest abroad through QDII, RQDII and other institutional arrangements. Since China's capital and financial accounts have not yet been fully opened to the outside world, the ways for domestic residents' foreign security investment are mainly QDII, RQDII, Shanghai-Hong Kong Stock Connect, Shenzhen-Hong Kong Stock Connect, QDIE and QDLP. With continuous opening of the capital account, the scale of China's foreign security investment has increased year by year. According to data released by the State 
Administration of Foreign Exchange in 2017, China's foreign security investment (excluding reserve assets) has reached US $\$ 497.7$ billion, of which equity investment is US $\$ 303.5$ billion and bond investment is US $\$ 194.2$ billion. Chinese investors mainly invest in more familiar Chinese companies in Hong Kong and Asia Pacific, and have less involvement in global stocks in developed financial markets such as the US and Japan. This is mainly due to late opening of China's capital projects; domestic investors have less knowledge of foreign markets, especially developed financial markets. Despite this, the profitability of China's foreign securities investment has been greatly improved in recent years (see Table 2-2). In 2017, return on investment of QDII funds reached to 23.62\%. While as main body of national wealth fund, the yield of foreign investment in China Investment Corporation also reached to $17.59 \%$.

Table2-2. 2008-2017 Major External Securities Investment Return Rate

\begin{tabular}{|l|l|l|}
\hline Year & QDII rate of return & CIC rate of return \\
\hline 2008 & $-43.35 \%$ & $-2.1 \%$ \\
\hline 2009 & $57.48 \%$ & $11.7 \%$ \\
\hline 2010 & $-10.61 \%$ & $11.7 \%$ \\
\hline 2011 & $-20.80 \%$ & $-4.3 \%$ \\
\hline 2012 & $10.36 \%$ & $10.60 \%$ \\
\hline 2013 & $5.02 \%$ & $9.33 \%$ \\
\hline 2014 & $2.82 \%$ & $5.47 \%$ \\
\hline 2015 & $-3.75 \%$ & $-2.96 \%$ \\
\hline 2016 & $6.54 \%$ & $6.22 \%$ \\
\hline 2017 & $23.62 \%$ & $17.59 \%$ \\
\hline Average rate of return & $2.73 \%$ & $6.33 \%$ \\
\hline
\end{tabular}

\section{AMOUNT OF CHINA'S CAPITAL EXPORT}

Productive and lending are two ways of capital export in China. Productive capital export mainly conducted through direct investment, while lending capital export includes government aid loans, buyer credit and QDII. The data of direct investment, government loans, buyer credit and security investment over the years can be aggregated to calculate the amount of China's capital export. Summing up the net asset data of direct investment, loans, trade credits, and portfolio investment in balance of payments, we can estimate the scale of capital exports over the years (see table 3-1).

Table3-1. China's Capital export from year 2000 to 2019

\begin{tabular}{|l|l|l|l|l|l|}
\hline & Direct investment & loans & Trade credits & Security investment & Capital export \\
\hline 2000 & 9.16 & 184.30 & 129.60 & 113.07 & 436.13 \\
\hline 2001 & 68.85 & $(153.14)$ & $(7.02)$ & 206.54 & 115.23 \\
\hline 2002 & 25.18 & 53.91 & $(10.98)$ & 120.95 & 189.06 \\
\hline 2003 & 0.12 & $(138.45)$ & 14.65 & $(29.93)$ & $(153.61)$ \\
\hline 2004 & 19.63 & 177.75 & 158.97 & $(65.40)$ & 290.95 \\
\hline 2005 & 137.30 & 129.68 & 229.05 & 261.57 & 757.6 \\
\hline 2006 & 239.32 & $(43.19)$ & 261.48 & 1112.78 & 1570.39 \\
\hline 2007 & 171.55 & 208.23 & 238.00 & 45.22 & 663 \\
\hline 2008 & 567.42 & 185.01 & $(58.67)$ & $(251.98)$ & 441.78 \\
\hline 2009 & 438.90 & $(30.95)$ & 342.71 & 25.26 & 775.92 \\
\hline 2010 & 579.54 & 210.41 & 616.35 & 76.43 & 1482.73 \\
\hline 2011 & 484.21 & 452.75 & 709.58 & $(62.48)$ & 1584.06 \\
\hline 2012 & 649.63 & 653.32 & 618.12 & 63.91 & 1984.98 \\
\hline 2013 & 729.71 & 319.47 & 602.66 & 53.53 & 1705.37 \\
\hline 2014 & 1231.30 & 737.87 & 687.56 & 108.15 & 2764.88 \\
\hline 2015 & 1743.91 & 474.64 & 459.66 & 732.09 & 3410.3 \\
\hline 2016 & 2164.24 & 1102.67 & 1008.00 & 1027.70 & 5302.61 \\
\hline 2017 & 1382.93 & 434.66 & 194.00 & 948.03 & 2959.62 \\
\hline 2018 & 1430.27 & 818.30 & 653.00 & 535.07 & 3436.64 \\
\hline 2019 & 977.03 & $(331.31)$ & $(368.00)$ & 894.19 & 1171.91 \\
\hline
\end{tabular}

Data sources: http://www.safe.gov.cn/safe/2019/0627/13519.html Unit: billion CNY

\section{IMPACT OF CAPITAL EXPORT ON CHINA'S ECONOMIC GROWTH}

\subsection{Overall Impact of Capital Export on China's Economic Growth}


What is the current role of China's capital export on economic growth? To study this problem, this part builds an ARDL model. The model uses quarterly growth rate of capital export (CE) as explanatory variable, and the relevant data is estimated based on the quarterly data from china's balance of payments in year from 2000 to 2019. The interpreted variable selects quarterly growth rate of gross domestic production (GDP), and the data comes from website of National Bureau of Statistics. The statistical characteristics of relevant variables are as follows:

Table4-1. Statistical characteristics of indicators

\begin{tabular}{|l|l|l|l|l|}
\hline \multicolumn{1}{|c|}{ indicators } & \multicolumn{1}{c|}{ mean } & \multicolumn{1}{c|}{ Standard deviation } & \multicolumn{1}{c|}{ minimum } & \multicolumn{1}{c|}{ maximum } \\
\hline Capital export (CE) & 1.071778 & 5.726040 & -8.788622 & 44.80484 \\
\hline $\begin{array}{l}\text { Growth rate of } \\
\text { GDP (GDP) }\end{array}$ & 0.036013 & 0.109899 & -0.197638 & 0.138088 \\
\hline
\end{tabular}

In order to verify whether there is a long-term equilibrium relationship between CE and GDP, unit root test is first carried out. The test results show that $\mathrm{CE}$ is stationary sequences at $1 \%$ significant level, while GDP variable is not stationary sequences at $1 \%$ significant, but its first-order difference series is stationary. Therefore, GDP variable is a first-order differential stationary series.

Table4-2. Stationarity test of variables

\begin{tabular}{|l|l|l|l|l|l|l|}
\hline factors & $(\mathbf{C}, \mathbf{T}, \mathbf{L})$ & ADFtest & $\mathbf{1 \% l e v e l}$ & $\mathbf{5 \% l e v e l}$ & $\mathbf{1 0 \% l e v e l ~}$ & D.W.stat \\
\hline CE & $\left(\begin{array}{lll}0, & 0, & 0\end{array}\right)$ & -9.417744 & -3.515536 & -2.898623 & -2.586605 & 1.991254 \\
\hline GDP & $\left(\begin{array}{lll}0, & 0, & 0\end{array}\right)$ & -2.792321 & -3.520307 & -2.900670 & -2.587691 & 1.887150 \\
\hline DGDP & $\left(\begin{array}{lll}1, & 0, & 0\end{array}\right)$ & -5.117349 & -3.520307 & -2.900670 & -2.587691 & 1.794387 \\
\hline
\end{tabular}

Note: D represents the first-order difference of the sequence. C, T, and L in the test type represent the intercept term, trend term, and lag length in the test regression equation, respectively, 0 means no.

Because the variables involved in this study are of different orders of stability, conventional Johansen test model cannot be used. In this paper, auto regressive distribution lag model (ADRL model) is used for research. ADRL model can estimate time series of different orders of stability, the results are consistent and effective, long-term and short-term influence coefficients can be obtained. ARDL model with CE as explaining variable is as follows:

$$
\mathrm{GDP}_{t}=\alpha_{0}+\sum_{i=1}^{p} \beta_{i} G D P_{t-i}+\sum_{i=1}^{q} \alpha_{1 i} C E_{t-i}+\varepsilon_{t}
$$

Where, $\alpha_{0}$ is intercept term, $\beta_{i}$ is coefficient before the $\mathrm{i}$-th legged period interpreted variable, $\alpha_{1 i}$ is coefficient before the $\mathrm{i}$-th legged period explanatory variable, $\varepsilon_{t}$ is random error term, $\mathrm{p}$ and $\mathrm{q}$ are maximum lag order of interpreted variable and explanatory variable. Further, co-integration relationship test was carried out for each variable. Johansen co integration test showed that there is 2 co-integrating relationship at the significance level of 0.05 , indicating that there is a long-term stable equilibrium relationship among $\mathrm{CE}$ and GDP.

Table4-3. Johansen Co Integration Output of DCE and DGDP

\begin{tabular}{|l|l|l|l|l|}
\hline Hypothesized No. of CE(s) & Eigen value & Trace Statistic & 0.05 Critical Value & Prob.** \\
\hline None $*$ & 0.993474 & 422.5012 & 15.49471 & 0.0001 \\
\hline At most 1 * & 0.409804 & 40.07480 & 3.841466 & 0.0000 \\
\hline
\end{tabular}

* denotes rejection of the hypothesis at the 0.05 level

ARDL model was established using eviews9.0. Regression results of the model under AIC criteria are shown in Table 4-4. The impact coefficients of capital export (DCE) for the current period is $0.000499, \mathrm{p}$ value is 0.1298 。 Regression result shows that capital export has a certain positive impact on economic growth, but the impact is not strong. $\mathrm{R}^{2}$ is as high as 0.979358 , indicating that $97.9 \%$ information can be explained by the model, so the model can strongly interpret relationship between capital export and economic growth.

Table4-4. Result of ARDL Model

\begin{tabular}{|l|l|l|l|l|}
\hline & C & S.E & T & Prob \\
\hline GDP(-1) & -0.069899 & 0.047978 & -1.456895 & 0.1496 \\
\hline
\end{tabular}




\begin{tabular}{|l|l|l|l|l|}
\hline GDP(-2) & -0.070098 & 0.047958 & -1.461646 & 0.1483 \\
\hline GDP(-3) & -0.081623 & 0.047707 & -1.710908 & 0.0915 \\
\hline GDP(-4) & 0.899624 & 0.047823 & 18.81151 & 0.0000 \\
\hline CE & 0.000499 & 0.000325 & 1.532976 & 0.1298 \\
\hline C & 0.010806 & 0.006947 & 1.555400 & 0.1244 \\
\hline$R^{2}=0.979358$ & adjusted $R^{2}=0.977884$ & D.W. $=1.097733$ \\
\hline
\end{tabular}

Further unit root test of the residual sequence of ARDL model shows that the residual sequence is stable at the $1 \%$ confidence level, indicating that there is a long-term relationship between capital export and economic growth.

Table4-5. Unit root test of ECM

\begin{tabular}{|l|l|l|l|l|}
\hline ADFtest & 1\%level & 5\%level & 10\%level & D.W.stat \\
\hline-5.299720 & -3.520307 & -2.900670 & -2.587691 & 1.836041 \\
\hline
\end{tabular}

After obtaining long-term coefficient, an error correction model (ECM) is further constructed to study short-term dynamic adjustment process of each explanatory variable to the interpreted variable. The ECM model is constructed as follows:

$$
\mathrm{DGDP}=c+\sum_{i=1}^{q} \lambda_{1 i} \mathrm{D} G D P_{t-i}+\sum_{i=1}^{q} \lambda_{2 i} \mathrm{DCE} E_{t-i}+\theta e(-1)
$$

Where e is error correction term, coefficient $\lambda$ reflects influence coefficient of short-term fluctuation of explanatory variable $\mathrm{CE}$ on short-term fluctuation of interpreted variable, and coefficient $\theta$ reflects adjustment speed when equilibrium relationship deviates from long-term level. The model regression results (as shown in Table 4-6) show that short-term fluctuation of capital export has positive effect on GDP fluctuation, and the error correction term ECM(-1) has a negative coefficient. The adjustment direction is in line with expectations, and is significant at the level of $1 \%$. The test shows that a shortterm deviation can be restored to long-term equilibrium state with the voluntary fluctuation of the economy. Specifically, when economic fluctuations are deviated from long-term equilibrium by shortterm effects, the system will adjust to a long-term equilibrium at a rate of $97.94 \%$.

Table4-6. Output of ECM

\begin{tabular}{|l|l|l|l|l|}
\hline & C & S.E & T & Prob \\
\hline C & 0.004223 & 0.021618 & 0.195330 & 0.8457 \\
\hline DCE & 0.003235 & 0.002602 & 1.243565 & 0.2177 \\
\hline E(-1) & -0.979421 & 1.418505 & -0.690460 & 0.4921 \\
\hline R $^{2}=0.023696$ & adjusted $R^{2}=0.003424$ & D.W. $=3.267303$ \\
\hline
\end{tabular}

\subsection{Itemized Impact Analysis of Capital Export on Economic Growth}

In order to test impact of different types of capital export on economic growth, this section builds model using quarterly growth rate of GDP (GDP) as interpreted variable, quarterly growth rate of direct investment (DI), loans (L), trade credit (TL) and security investment ( SI) as explanatory variables. The statistical characteristics all data is shown in Table 4-7:

Table4-7. Statistical characteristics of relevant indicators

\begin{tabular}{|l|l|l|l|l|}
\hline indicators & mean & Standard deviation & minimum & maximum \\
\hline DI & 1.580457 & 9.499259 & -4.970197 & 78.06349 \\
\hline L & -1.289917 & 3.972833 & -20.79846 & 8.364745 \\
\hline TL & -2.314899 & 14.44724 & -95.64874 & 13.43890 \\
\hline SI & 2.689654 & 26.81794 & -17.49752 & 234.1956 \\
\hline GDP & 0.036013 & 0.109899 & -0.197638 & 0.138088 \\
\hline
\end{tabular}

Results of stationary test show that the relevant variables DI, L, TL, SI are all Stationary sequence, while GDP is first-order differential stationary sequences (see table 4-8).

Table4-8. Result of stationary test

\begin{tabular}{|l|l|l|l|l|l|l|}
\hline indicators & $(\mathbf{C}, \mathbf{T}, \mathbf{L})$ & ADFtest & $\mathbf{1 \% l e v e l ~}$ & 5\%level & 10\%level & D.W.stat \\
\hline DI & $\left(\begin{array}{lll}0, & 0, & 0\end{array}\right)$ & -9.320925 & -3.515536 & -2.898623 & -2.586605 & 2.002281 \\
\hline L & $\left(\begin{array}{lll}0, & 0, & 0\end{array}\right)$ & -8.803777 & -3.515536 & -2.898623 & -2.586605 & 1.997820 \\
\hline
\end{tabular}




\begin{tabular}{|c|c|c|c|c|c|c|}
\hline TL & $(0,0,0)$ & -8.875728 & -3.515536 & -2.898623 & -2.586605 & 2.000082 \\
\hline SI & $(0,0,0)$ & -8.879816 & -3.515536 & -2.898623 & -2.586605 & 2.000394 \\
\hline GDP & $(0,0,0)$ & -2.792321 & -3.520307 & -2.900670 & -2.587691 & 1.887150 \\
\hline DGDP & $(\mathrm{C}, 0,0)$ & -5.117349 & -3.520307 & -2.900670 & -2.587691 & 1.794387 \\
\hline
\end{tabular}

Based on stability characteristics of each sequence, an ARDL model can be constructed as follow:

$$
\mathrm{GDP}_{t}=\alpha_{0}+\sum_{i=1}^{p} \alpha_{1 i} G D P_{t-i}+\sum_{i=1}^{q} \alpha_{2 i} \mathrm{DI}_{t-i}+\sum_{i=1}^{q} \alpha_{3 i} \mathrm{~L}_{t-i}+\sum_{i=1}^{q} \alpha_{4 i} T L_{t-i}+\sum_{i=1}^{q} \alpha_{5 i} P I_{t-i}+\varepsilon_{t} \quad \text { For }
$$

explanatory terms, $\alpha_{t i}$ are variable coefficients of i period legged. $\varepsilon_{t}$ is random error term. $\mathrm{p}$ and $\mathrm{q}$ are the maximum lag order of the interpreted variable and the explanatory variable respectively. Johensen co integration test results show that there is at least 5 cointegration relationship at 5\% confidence level, there is a long-term stable equilibrium relationship among all variables.

Table4-9. Result of Johensen Co integration Test

\begin{tabular}{|l|l|l|l|c|}
\hline Hypothesized No. of CE(s) & Eigen value & Trace Statistic & 0.05 Critical Value & Prob.** \\
\hline None * & 0.915862 & 280.7587 & 69.81889 & 0.0000 \\
\hline At most $*^{*}$ & 0.326274 & 90.16096 & 47.85613 & 0.0000 \\
\hline At most ${ }^{*}$ & 0.290266 & 59.75118 & 29.79707 & 0.0000 \\
\hline At most $*$ & 0.227399 & 33.35060 & 15.49471 & 0.0000 \\
\hline At most 4* & 0.160653 & 13.48514 & 3.841466 & 0.0002 \\
\hline
\end{tabular}

Eviews9.0 is used to establish ARDL model. Optimal result of the model under AIC criteria is shown in Table 4-10. The result shows that four sub-indicators of direct investment, loans, trade credit and security investment have different effects on GDP. Among them, direct investment have an impact coefficient of -0.000203 , indicating that Direct investment has a slight negative impact on economic growth; The influence coefficient of security investment and loans are also negative, indicating that the security investment and loans are all have slight negative impact on economic growth. Coefficient of trade loan is positive, but its impact is tinny. $\mathrm{R}^{2}$ is as high as 0.979687 , indicating that the model can strongly interpret their relationships.

Table4-10. Output of ARDL Model

\begin{tabular}{|l|l|l|l|l|}
\hline & C & S.E & T & Prob \\
\hline GDP(-1) & -0.080898 & 0.050724 & -1.594855 & 0.1155 \\
\hline GDP(-2) & -0.068530 & 0.049626 & -1.380919 & 0.1719 \\
\hline GDP(-3) & -0.088881 & 0.050888 & -1.746598 & 0.0853 \\
\hline GDP(-4) & 0.890629 & 0.051557 & 17.27454 & 0.0000 \\
\hline DI & -0.000203 & 0.000207 & -0.984699 & 0.3283 \\
\hline SI & $-5.40 \mathrm{E}-05$ & $7.25 \mathrm{E}-05$ & -0.743910 & 0.4595 \\
\hline L & -0.000650 & 0.000513 & -1.265274 & 0.2102 \\
\hline TL & $7.31 \mathrm{E}-05$ & 0.000135 & 0.540253 & 0.5908 \\
\hline C & 0.012066 & 0.007258 & 1.662279 & 0.1011 \\
\hline $\mathrm{R}^{2}=0.979687$ & \multicolumn{2}{|l|}{ adjusted $\mathrm{R}^{2}=0.977262$} & D.W. $=1.039962$ \\
\hline
\end{tabular}

Unit root test of residual sequence is performed, the result shows that the residual sequence passes the stationary test within the $1 \%$ confidence level (see table 4-11), and there is a long-term relationship between explanatory variables and economic growth.

Table4-11. Unit Root Test of Residual Sequence

\begin{tabular}{|l|l|l|l|l|}
\hline ADFtest & 1\%level & 5\%level & 10\%level & D.W.stat \\
\hline-4.882452 & -3.521579 & -2.901217 & -2.587981 & 2.029811 \\
\hline
\end{tabular}

Finally, an error correction model (ECM) is constructed to study short-term dynamic adjustment. ECM model is constructed as follows:

$$
D G D P=c+\sum_{i=1}^{q} \alpha_{1 i} D G D P_{t-i}+\sum_{i=1}^{q} \alpha_{2 i} D D I_{t-i}+\sum_{i=1}^{q} \alpha_{3 i} D L_{t-i}+\sum_{i=1}^{q} \alpha_{4 i} D T L_{t-i}
$$




$$
+\sum_{i=1}^{q} \alpha_{5 i} D P I_{t-i}+\theta e_{1}(-1)
$$

Among them, el is error correction term, coefficient $\alpha$ reflects the influence coefficient of short-term fluctuation of each explanatory variable on short-term fluctuation of GDP. The coefficients $\theta$ and $\varphi$ reflect adjustment speed when equilibrium relationship deviates from long-term level. The model regression results are shown in Table 4-12. Coefficient of error correction term e1(-1) is negative. The direction is in line with expectations, and the test is passed at a significant level of $1 \%$, indicating that short-term deviation can be restored to a long-term equilibrium state with facing economic fluctuation.

Table4-12. Result of ECM)

\begin{tabular}{|l|l|l|l|l|}
\hline & C & S.E & T & Prob \\
\hline C & 0.003044 & 0.014775 & 0.205991 & 0.8374 \\
\hline DDI & 0.001724 & 0.001065 & 1.618395 & 0.1102 \\
\hline DL & -0.007230 & 0.002695 & -2.682640 & 0.0092 \\
\hline DTL & $1.62 \mathrm{E}-05$ & 0.000763 & 0.021215 & 0.9831 \\
\hline DSI & 0.000348 & 0.000384 & 0.905006 & 0.3687 \\
\hline DGDP(-1) & -0.680050 & 0.083825 & -8.112776 & 0.0000 \\
\hline e1(-1) & -0.146527 & 0.970289 & -0.151014 & 0.8804 \\
\hline $\mathrm{R}^{2}=0.569169$ & adjusted $\mathrm{R}^{2}=0.531154$ & $\mathrm{D} . \mathrm{W} .=2.338662$ \\
\hline
\end{tabular}

\section{Conclusion}

This study explores relationship between china's capital export and economic growth. Empirical analysis shows that China's capital export has little positive impact on economic growth. However, direct investment, which is one of main forms of capital export, has significant negative impact on China's economic growth. This conclusion is conflict to researches on early developed countries. While, as another major form of capital export, long-term impact of security investment on economic growth is also slightly negative. Loan has negative effect on GDP too. Only trade loan has slightly positive impact on economic growth.

\subsection{Why Doesn't Direct Investment Promote Economic Growth?}

China's foreign direct investment mainly invests in Asian and Latin American countries. Investment in this two regions accounts for more than $78 \%$ of total foreign direct investment of China, while investment in developed America and Europe accounts for less than 20\% of total investment. $74 \%$ of investment in Asia is invested in Hong Kong, and 94.8\% of the investment in Latin America is invested in Cayman Islands and British Virgin Islands. Funds invested to Hong Kong are driven by blood relation, culture and government policy preferences, while funds invested to Cayman and the British Virgin Islands are driven by tax avoidance and lower operating costs. Invest in Cayman and the British Virgin Islands allow companies to invest to some sensitive area using the two islands as a transit. Moreover, some funds invested in Hong Kong and the two islands were transferred reversely to domestic market in form of foreign capital to enjoy domestic preferential policies provided to foreign-funded enterprises. These direct investments in transit cannot create economic benefits abroad and thus cannot promote economic growth.

From the perspective of industry structure, China's foreign direct investment accounted for the largest proportion of tertiary industry, accounting for more than $70 \%$ of the total outward investment. Secondary industry accounted for more than $20 \%$, and primary industry accounted for only about $1 \%$ to foreign direct investment. High proportion of tertiary industry investment is mainly concentrated in traditional industries such as leasing, business services, wholesale and retail industries. Proportion of service industry based on advanced management concepts and modern information technology is low. Low proportion of secondary industry reflects an unfavorable global competitive of China's manufacturing industry in the world, which is not conducive to the development of comparative advantage of manufacturing industry, also it is harmful to the transfer of excess product capacity. Beside of this, in foreign investment of manufacturing industry, the investment in industries with high 
added value and high technology is less. The distribution of industry structure makes foreign direct investment have little effect on domestic technological progress; technology spillover mechanism cannot play a role.

In China some foreign direct investment may be capital flight, For example, some domestic companies acquire foreign companies that are on the verge of bankruptcy, and the acquisition entity itself has no relevant industry experience. The nature of such investment is may be capital flight in its essential. There are other examples, such as, some domestic enterprises establish branches abroad, and remit large sums of money to foreign subsidiaries in the name of repaying debts; Some companies retain the profits of foreign subsidiaries in the form of profit reinvestment abroad. These fugitive funds are counted in foreign direct investment in official statistics, but no new income is generated after the funds flow out, which not only causes loss of domestic funds, but also has have a negative inhibitory effect on economic growth.

\subsection{Solutions}

At present, China's foreign direct investment has a certain degree of blindness. Both government and enterprise pursue increasing scale of foreign direct investment, ignoring investigation of the rationality and profitability of investment. Foreign direct investment should be changed from scaleoriented to quality-oriented. The location of China's foreign direct investment is concentrated in Asia and Latin America. Direct investment in the two regions accounts for more than $70 \%$ of the total foreign direct investment. Compared with Asia and Latin America, developed countries have more opportunities, enterprises can try to open up investment markets in developed countries outside Asia and Latin America with low investment barriers. China's foreign direct investment is mainly concentrated in tertiary industry; the investment in the secondary industry is mainly concentrated in mining and manufacturing. Unreasonable industrial layout is one reason for China's foreign direct investment to have poor returns. Therefore, in the adjustment of industrial layout, we should encourage high-tech, mature manufacturing enterprises to invest abroad, transferring labor-intensive manufacturing companies with overcapacity to leave room for the development of high-end manufacturing. Improve the capacity of direct investment in trade promotion, employment, technology Improvement is needed. Also, domestic investment environment should be improved.

The opening of the capital account has a positive effect on promoting a country's economic growth and diversifying international risks. The practical experience of developed countries has fully proved this. However, for developing countries, the opening of the capital account is a double-edged sword. Capital account opening up can promote economic growth and diversify risks; it also faces greater financial system volatility and financial crisis, which is mainly due to the development of financial markets in developing countries. At present, China's capital account opening is still in the stage of promotion. So, capital account opening still needs to be continued.

\section{REFERENCES}

[1] Aaron Tornell and Andres Velasco. The Tragedy of the Commons and Economic Growth: Why Does Capital Flow from Poor to Rich Countries?[J] Journal of Political Economy.1992,100(6): 1208-1231.

[2] Chales P. Kindleberger. A Financial History of Western Europe. George Allen \& Unwin (Publishers) Ltd. 1984.

[3] Chales P. Kindleberger, Peter H. Lindert. International Economics. McGraw-Hill Higher Education. 1978.

[4] Dunning, John. Locations and multinational Enterprises: A Neglected Factor?[J]. Journal of International Business Studies, 2009,29(1):45-66.

[5] Kogut,B.and Chang,S. Technological Capabilities and Japanese Foreign Direct Investment in the United States[J].The Review of Economics and Statistics,1991(73):401-413.

[6] Lucas, Robert E. Why Doesn't Capital Flow from Rich to Poor Countries [J]? The American Economic Review, 1990, 80(2):92-96.

[7] Mundell, R. A. International trade and factor mobility [J]. American Economic Review. 1957, 47(3), 321335.

[8] Robert Gilpin, U.S. Power and the multinational corporation: the political economy of foreign direct investment, New York: Basic Books,Inc,Publishers, 1975.

[9] Ralph George Hawtrey. Good and bad trade: an inquiry into the causes of trade fluctuation. [M] . Constable \&company limited, 1913. 
[10] Raymond Vernon. International Investment and International Trade in the Product Cycle[J]. The Quarterly Journal of Economics, 1966(5), Vol. 80, No. 2 :190-207.

[11] Reinhart, Carmen M, Kenneth s. Rogoff. Serial Default and the Paradox of Rich to Poor Capital Flows. American Economic Review.2004, 94(2):53-58.

[12] Vernon. R. International investment and international trade in the product cycle. Quarterly Journal of Economics. 1966,80.190-207.

\section{AUTHOR'S BIOGRAPHY}

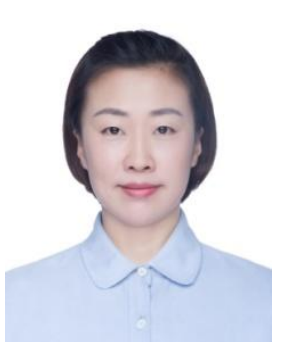

Han Ping, holds a Master of economics and currently working at School of Economics and Management in ShanDong JiaoTong University, Jinan, Shandong, China. She has been engaged in teaching and research of economics and finance with more than 20 related papers publicized, and many papers have been published in Chinese core journals. She has hosted and participated in more than 10 projects, including 2 provincial projects and many municipal projects. Her pedagogic interests are International finance and financial derivatives.

Citation: Ping Han. "Capital Export and Economic Growth - The Case of China" International Journal of Managerial Studies and Research (IJMSR), vol 8, no. 6, 2020, pp. 55-65. doi: http:// dx.doi.org/10.20431/23490349.0806006.

Copyright: (C) 2020 Authors. This is an open-access article distributed under the terms of the Creative Commons Attribution License, which permits unrestricted use, distribution, and reproduction in any medium, provided the original author and source are credited. 